\author{
Longina Strumska-Cylwik \\ Uniwersytet Gdański
}

\title{
Rozważania nad zagadnieniem przedsiębiorczości w kontekście otwartości czlowieka na świat
}

Tematem moich rozważań jest problem przedsiębiorczości postrzegany w kontekście otwartości człowieka na świat. Jako badacz problemu otwartości, zauważyłam szereg korelacji zachodzących między zagadnieniami otwartości i przedsiębiorczości człowieka, które ilustrują załączone do tekstu schematy (zob. schemat nr 1 -Matryca otwartości, schemat nr 2 - Matryca przedsiębiorczości oraz schemat nr 3 - obrazujący różne strategie myślenia).

Są one oparte zarówno na studiach teoretycznych, jak i praktycznych i stanowią odzwierciedlenie najczęstszych opisów, wyjaśnień, charakterystyk i interpretacji omawianych pojęć. Pozwalają jednocześnie dostrzec wiele wspólnych cech w omawianych terminach, na przykład: kreatywność, odwaga, elastyczność, rozwojowość, aktywność etc.

Skłoniło mnie to do przyjęcia pewnego założenia, a mianowicie: że przedsiębiorczość człowieka w dużej mierze uwarunkowana jest jego otwartością na świat i innych ludzi.

Powszechnie uznaje się otwartość za cechę pozytywną, za zaletę, co oczywiście tylko pozornie może wydawać się prawdziwe. Kiedy sięgniemy do głębszych warstw rozumienia pojęcia, okazuje się, że posiada również silne zabarwienia pejoratywne. Na przykład: otwarta rana, otwarta wojna, otwarty konflikt, i wiele innych.

Ludzie otwarci jednakże, są na ogół utożsamiani z ludźmi życzliwymi, komunikatywnymi, empatycznymi, kreatywnymi. Sama otwartość zaś kojarzona jest jako stan pożądany, pogłębiający związki między ludźmi, sprzyjający rozwojowi, przyjaźni, zapewniający właściwe relacje interpersonalne, zwiększający kreatywność człowieka, pomagający rozwiązywać problemy, a także osiagać sukcesy etc.

W tych ostatnich dostrzegamy wyraźne związki otwartości z zagadnieniem przedsiębiorczości, albowiem człowiek przedsiębiorczy charakteryzowany jest jako człowiek ,umiejący załatwić wszystkie sprawy, pełen inicjatywy, energii, pomysłowy, zaradny, rzutki". ${ }^{1}$

„Mający ducha inicjatywy, skory do podejmowania różnych spraw (...)"2.

Według Peter Drucker'a - „każdy, kto ma odwagę podjąć decyzję, może nauczyć się prowadzić biznes (...) przedsiębiorca zawsze poszukuje zmiany, reaguje na nią i wykorzystuje ją jako okazję". 3

\footnotetext{
${ }^{1}$ Mały słownik języka polskiego pod red. Stanisława Skorupki, Haliny Auderskiej, Zofii Łempickiej, Wiedza Powszechna, Warszawa 1974. op. cit, s. 643.

${ }^{2}$ Słownik języka polskiego, pod red. Mieczysława Szymczaka, PWN, Warszawa1979, op. cit. tom II, s. 968.

${ }^{3}$ Pojęcie przedsiębiorcy, op. cit. strona internetowa: www.ipis.pl (04.08.23).
} 
Schemat 1 - Matryca znaczeń

*Umiejętność widzenia siebie

takim, jakimi się jest

*Odwaga odkrywania nowej

wiedzy o sobie i w ogóle

*Odwaga bycia sobą
*Dyskursywny charakter wszelkiej wiedzy

*Rozum ,transwersalny" W. Welsch (1998)

*Kreatywność

*Otwartość na poziomie myślenia i działania, na poziomie ciała i werbalnego komunikowania się oraz na poziomie emocji.

*Gotowość do wzajemnej wymiany perspektyw (sprzężeń zwrotnych)

*Życzliwość, tolerancja, empatia

*Otwartość na nową wiedzę, wyzwania, ,inność", „odmienność"

*Zdolność do ,dialektycznego myślenia", dialektycznego zadawania pytań (do dokonywania ,bisocjacji”dwójkojarzenia)

*Otwartość nieufna, ironiczna, pojmowana po ,rortiańsku” (Richard Rorty, Andrzej Szahaj 1996)

*Otwartość ,racjonalna" „kontrolowane transgresje" Józef Kozielecki (1987);

Chantal Delsol (2001) wpisane w otwartość.
*,Wychodzenie poza siebie”„bycie poza sobą" Zbigniew Kwieciński (2000), Paul Ricoeur (2003)

*,Transparentność”- przejrzystość

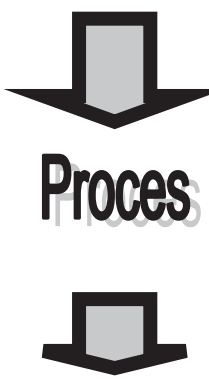

S. Jourard (1970)
Rozwój

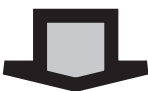

*Umiejętność antycypowania przyszłości Jaques Delors,(1998)

*Szczerość, jawność, bezpośredniość, prostolinijność (synonimy otwartości)

*,Dezintegracja pozytywna”, „trud istnienia” - „Per Aspera ad Astra” Czesław Miłosz (1989), Kazimierz Dąbrowski $(1975,1979)$.

Źródło: Opracowanie własne 
Schemat 2 - Matryca znaczeń „Przedsiębiorczość”

*Zdolność człowieka do kreowania i zaspokajania swoich i cudzych potrzeb

Tworzenie otoczenia poprzez jego rekonfigurację, restrukturalizację (wyjście ponad podwójną

pętlę) [Stefan Kwiatkowski]

\section{*Aktywność \\ *Inicjatywa}

*Krytycyzm

* Kreatywność

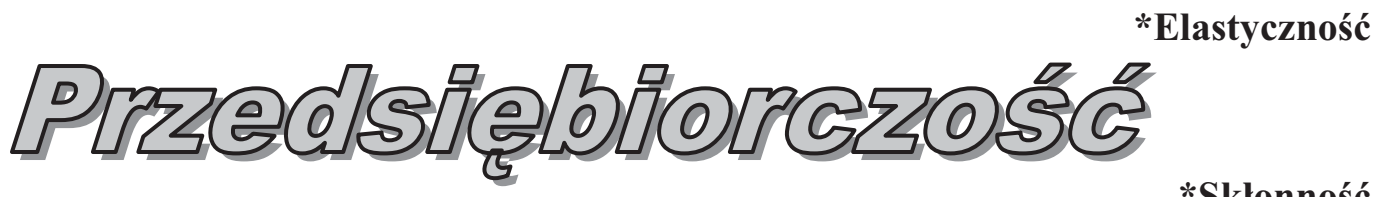

*poszukiwanie zmiany i reagowanie naz mianę do redefiniowania otoczenia

*Wykorzystywanie czynnika niepewności i ryzyka oraz podejmowanie ryzyka (RACJONALNOŚĆ - ANTYCYPOWANIE PRZYSZŁOŚCI) [PeterDrucker]

*Wprowadzanie nowych kombinacji Pomysłowość (Joseph Schumpeter)

*Radzenie sobie ze strachem

*Rzutkość przed porażką

*Rozwojowość

Źródło: Opracowanie własne 
Schemat 3

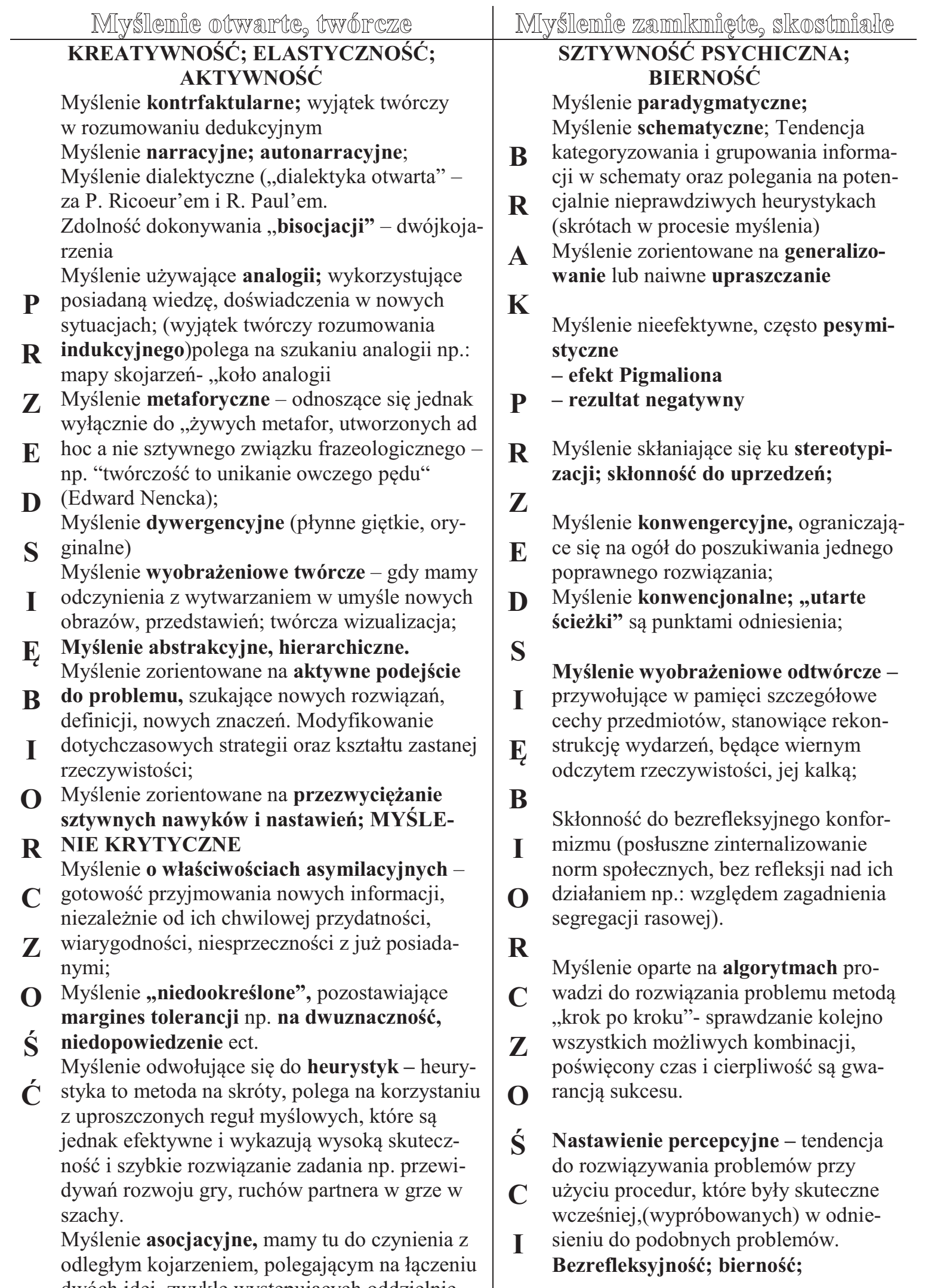


Przez naukę przedsiębiorczości rozumiemy tym samym nie tylko „zdobywanie wiedzy i umiejętności w zakresie najbardziej przydatnym dla funkcjonowania w życiu społeczno-gospodarczym. Problematykę tę widzimy szerzej, jako różnorodne rodzaje aktywności prowadzace do rozwoju człowieka, życia $w$ dostatku i harmonii z innymi ludźmi". ${ }^{4}$

Kiedy myślimy, bądź mówimy o otwartości na ogół sytuujemy ją w kontekście samootwartości, postaw życiowych, bądź komunikacji interpersonalnej (zazwyczaj życzliwej i przyjacielskiej), co doskonale odzwierciedla prezentowany poniżej The Johari Window Model.

Okno Johari Window „Poznaj mnie” oparte jest na modelu ujawniania informacji zwrotnej dotyczącej bycia świadomym czegoś. Owo bycie świadomym czegoś jest istotne nie tylko w kontekście problemu otwartości. W moim przekonaniu, wydaje się równie inspirujące i znaczące w kontekście zagadnienia przedsiębiorczości.

Wszystko, co się wokół nas dzieje, przechodzi do naszego Ukrytego Ja.

Część z tych informacji zapominamy, więc przechodzą one do Nieznanego Ja. Niektóre $\mathrm{z}$ doświadczeń wzmacniają nasze nieuświadomione przyzwyczajenia, nawyki i tym samym wędrują do naszego ślepego Ja. Jeszcze inne pamiętamy, lecz ich nie ujawniamy, toteż pozostają one w Ukrytym Ja.

W końcu inne informacje zauważamy, dzielimy się nimi z innymi, co oznacza, że przechodzą one do Otwartego Ja. Wtedy wzrasta nasza samoświadomość, stajemy się tym samym bardziej przewidywalni (transparentni) dla innych.

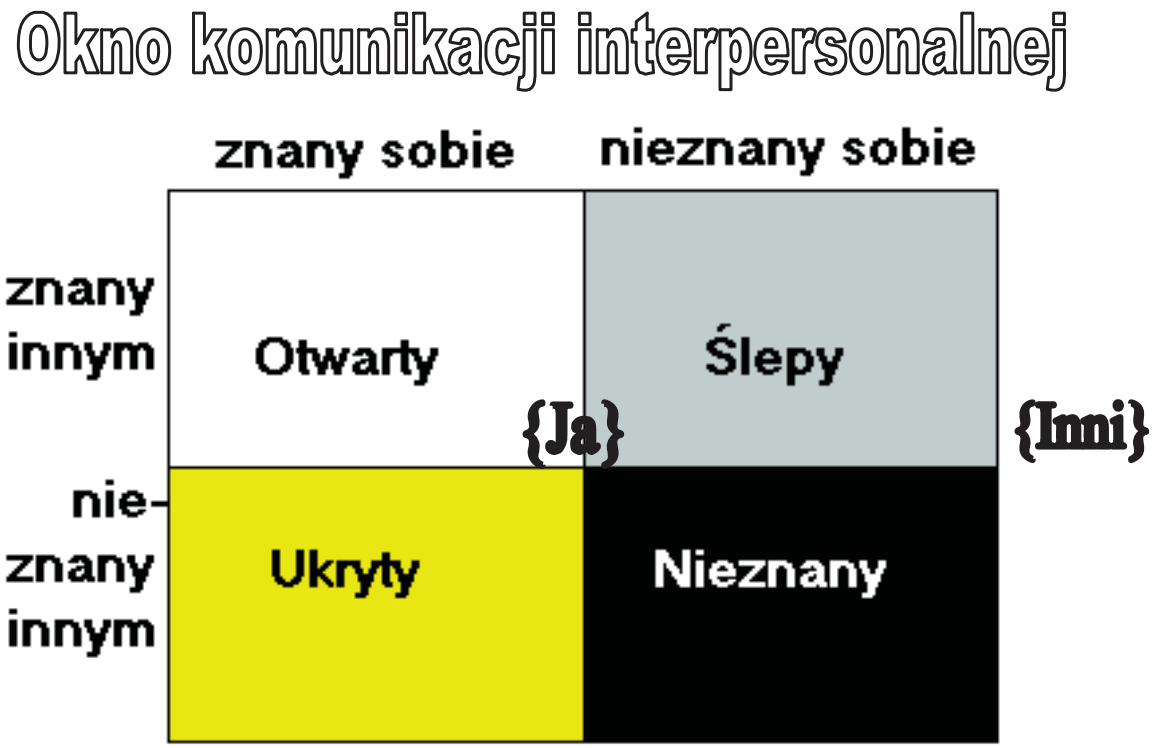

Źródło: J. Luft, H. Ingham (1955).

I) Pierwsza ćwiartka okna ilustruje tzw. obszar Otwarty - Otwarte Ja - to obszar wiedzy o nas, który jest znany zarówno sobie jak i innym. Ten obszar jest częścią świadomego" siebie"(świadome działania i wypowiedzi); w sferze naszego zachowania, motywacji, wartości, stosunków do różnych zagadnień. Dotyczy wszystkiego, czego zarówno my sami jesteśmy świadomi, jak i nasze otoczenie.

II) Druga ćwiartka okna - to tzw. obszar Ślepy - Ślepe Ja - to obszar wiedzy nie znany sobie, ale znany innym, dotyczy tego czego nie jesteśmy świadomi (na przykład nawyków, sposobu bycia, mechanizmów obronnych, strategii walki, przyzwyczajeń).

\footnotetext{
${ }^{4}$ Przedsiębiorczość, op. cit. strona internetowa: www.wsip.com.pl (04.08.22)
} 
III) Trzecia ćwiartka obrazuje tzw. Ukryty obszar - Ukryte Ja - to obszar wiedzy, którą my sami posiadamy, lecz nie udostępniamy jej innym. W ukrytej płaszczyźnie okna mamy zatem nasze tabu, sekrety, myśli, uczucia, pragnienia, obawy, fantazje, których nie chcemy ujawniać innym ludziom. Stopień, do którego dzielimy się sobą z innymi (otwieramy się) jest to stopień, do jakiego inni wiedzą coś o nas. Nasz ukryty obszar nie może być znany innym dopóty, dopóki go przed nimi nie ujawnimy.

IV) Czwarta ćwiartka okna ilustruje obszar wiedzy nieznanej nikomu - to tzw. obszar Nieznany - Nieznane Ja. W tej płaszczyźnie okna są zatem te nasze cechy, właściwości, o których ani my nie wiemy, ani inni nie wiedzą o nas - np. jakiś uraz z okresu wczesnego dzieciństwa, o którym nie pamiętamy, który został stłumiony, a który może wpływać na nasze obecne relacje $\mathrm{z}$ innymi ludźmi. Istnienie tego obszaru sprawia, iż człowieka należy uznać jako istotę niepoznawalną i nieprzewidywalną do końca. Albowiem część wiedzy zawarta $\mathrm{w}$ jego podświadomości i nieświadomości pozostaje niedostępna dla nikogo.

Podział okna na cztery części zaproponowany w modelu okna Johari nie jest sztywny, jego poszczególne części nie są zamknięte. Towarzyszące człowiekowi każdego dnia obserwacje, myśli, uczucia, pragnienia stale poruszają się pomiędzy poszczególnymi sferami okna. Wielkość poszczególnych płaszczyzn okna w dużej mierze zależy od aktywności podmiotu, jego inicjatywy (przedsiębiorczości), chęci i dążności do wywoływania zmiany. Jeżeli zmieniamy coś w jednym obszarze okna, na jednej jego płaszczyźnie, to jednocześnie zmieniamy coś w innym obszarze. Zauważamy, że otwartość wykazuje nierozerwalny związek z samoświadomością, dokonywaniem transgresji, aktywnością podmiotu.

Zamknięcie natomiast z wypieraniem swojego prawdziwego „Ja” (thumieniem i hamowaniem przeżywanych emocji, co pociąga ze sobą ryzyko zahamowania rozwoju całej osobowości i kryzysu tożsamości. Niejednokrotnie wiąże się także z biernościa, wycofaniem, zakładaniem „Maski” - gdzie maska- to nie ,ja”. Maska ma chronić przed kolejnymi zranieniami, bólem, cierpieniem, ośmieszeniem, ryzykiem. Może wyrażać ucieczkę przed rzeczywistością, ale także przed wysiłkiem (myślenia, działania), przed podejmowaniem odpowiedzialnych decyzji, koniecznością dokonania ,jakiejś” zmiany (co można wiązać z brakiem przedsiębiorczości). Zwracają na to uwagę Józef Kozielecki, Igor Kon Erich Fromm. Zamknięcie bowiem pozwala „płynąć z prądem”, ulegać mechanizmom konformistycznym. Oznacza to, że człowiek zamknięty unika ryzyka, jest bierny, pozbawiony inicjatywy, mało przedsiębiorczy.

Należy oczywiście podkreślić, że pewne mechanizmy „przymykające”, „domykające", czy nawet zamykające bywają konieczne, aby utrzymać ład, porządek, ciągłość, stałość. Takie mechanizmy wydają się niezbędne, aby mogły funkcjonować na przykład: organizacje (np. społeczne); systemy (np. edukacyjny, szkolny); programy (np: nauczania) etc. Bywają również sytuacje, gdy otwartość wywołuje zagrożenie, gdy stwarza niebezpieczeństwo w wymiarze indywidualnym, bądź społecznym. Przykładem może być chociażby historia państwa totalitarnego. Wskazuje ona na niską tolerancję zarówno wobec otwartości, jak i przedsiębiorczości, które były w owym czasie niepożądane, niewskazane, tępione, eliminowane. Za otwartość przychodziło niekiedy płacić wysoką cenę, toteż ograniczano wszelkie jej przejawy, albo wręcz powoływano rozmaite „sztuczne otwartości”, które egzystowały w ramach określonych ideologii i raczej symulowały otwartość, stwarzały jej pozory, aniżeli rzeczywiście nią były. W takiej rzeczywistości - wolności słowa i myśli pilnie strzegła cenzura. Wolność fizyczną ograniczano np. zamkniętymi granicami państwa, więzieniem); kształcenie zdominowane było (przymknięte) paradygmatem pedagogiki instrumentalnej sterowanej ideologicznymi przesłankami etc. Tutaj dostrzegamy również silne ograniczenie przedsiębiorczości człowieka (jego kreatywności, zaradności, inicjatywy, aktywności etc.)

Powszechnie uważa się, że brak umiejętności otwierania się i otwartości naraża jednostkę i grupę na przykre konsekwencje. Przypuszczam, że podobnie rzecz się ma w odniesieniu do braku przedsiębiorczości, gdy mamy do czynienia z osobą bierną, mało elastyczną, bojaźliwą. Powszechnie wiadomo, że niemożność otwarcia się jednego człowieka przed 
drugim człowiekiem powoduje w nim uczucie osamotnienia i izolacji. Brak otwartości znajduje również swoje negatywne odbicie $\mathrm{w}$ grupie, albowiem kontakt i praca z osobą ,zamkniętą", mało przedsiębiorczą osłabia efektywność pracy grupowej. Szczególnym zaś kosztem jest $\mathrm{z}$ jednej strony jej wyalienowanie oraz poczucie obcości w otaczającym świecie; z drugiej zaś strony jej zamykanie się na świat, ludzi, bierność życiowa, które sprawiają, że oni również zamykają się na nią. Powodować to może złą atmosferę w grupie i może wywoływać różne formy zamknięcia wśród jej członków.

Należy jednocześnie zaznaczyć, że człowiek zamknięty (mało przedsiębiorczy) to niejednokrotnie człowiek zraniony, motywowany lękiem (co podkreślają w swoich pracach Alexander Lowen oraz Erich Fromm). Zamknięcie, izolacja, niechęć przed manifestowaniem swojego prawdziwego ja wynikają z doświadczeń przeszłości. Stanowią „,skorupę” chroniącą przed kolejnymi zranieniami, ciosami, przed potencjalnym bólem i cierpieniem, porażką. Osłabiają jednocześnie aktywność, kreatywność, samodzielność jednostki, jej przedsiębiorczość.

Człowiek zamknięty bardzo często bywa nieufny, sceptyczny, bierny, wycofany. Nieufność może powodować niechęć przed nowym, nieznanym, ryzykiem. Gdy „nowe” atakuje „stare” - na przykład wiedzę, przyzwyczajenie, strategie myślenia i działania - to zmusza człowieka do działania, aktywności, do podjęcia jakiegoś ryzyka bądź odpowiedzialności. Wtedy też zamienia niejednokrotnie wygodną, stabilną sytuację - w sytuację dyskomfortu, chaosu, kryzysu.

Okazuje się, że świat, jaki nosimy w sobie łącznie z jego objaśnieniem, pojmowaniem, jest bardzo często tak bardzo silnie zakorzeniony, że nie chcemy się go pozbyć i chronimy go za wszelką cenę.

Otwartość pojmowana jako gotowość do przyjmowania nowych perspektyw, wiedzy, idei, strategii myślenia i działania niejednokrotnie zmusza nas do czynu, do konieczności porzucenia wygodnej pozycji, wyjścia ze skorupy i zmierzenia się z odpowiedzialnościa, ryzykiem, dyskomfortem, kryzysem, czyli zmusza nas do bycia przedsiębiorczymi.

W rezultacie naraża nas na ciągłe zmiany, na modyfikowanie aktualnego stanu wiedzy, zmianę poglądów oraz na życie z ambiwalencją. Tym samym jednakże wymusza na nas aktywność, przedsiębiorczość, a w konsekwencji rozwój. Człowiek otwarty nie może żyć w przeświadczeniu, że obraz jego świata jest jedynym, słusznym i jedynie prawdziwym obrazem. Jednakże człowiek zamknięty często żyje właśnie w takim przekonaniu i sceptycznie przyjmuje wszelkie nowości i zmiany. Wygodniej jest bowiem żyć w uporządkowanym, „poukładanym”, „uczesanym” świecie, w którym nikt niczego od nas nie chce, i w którym niczego nie trzeba zmieniać. Nie ma wtedy odpowiedzialności, niewygody, niepewności, potrzeby aktywności, inicjatywy.

Wygodniej zatem być sceptykiem odcinającym się w imię racjonalności i rozsądku od tego, co nieznane, odgradzającym się od „nowego”, od poszukiwań, ryzyka, działania refleksyjności i rozwoju. Człowiek „racjonalny” opiera się na faktach i dowodach - gdyż owa „racjonalność” tego wymaga. Nawet wtedy, gdy owe fakty i dowody są cudze i nie są jego dziełem. Człowiek taki, wbrew głoszonej „racjonalności” opiera jednakże swój obraz świata i swoją wiedzę na przekazach od innych, na przykład naukowców, historyków, i innych tzw. „autorytetów”. Nie są to fakty przez niego odkryte, ani dowody bezpośrednio przez niego zgromadzone. Człowiek zamknięty ma ukształtowane opinie, sądy, schematy, poglądy i sztywno, kurczowo się ich trzyma. Aby nie narażać się na ryzyko ich zmiany - poszukuje jedynie potwierdzeń dla nich, kolekcjonuje odpowiadające mu, wygodne fakty i dowody.

W świetle powyższego nie trudno zauważyć, że człowiek zamknięty nie często jest człowiekiem przedsiębiorczym, ale często jest bierny, wycofany, zachowawczy.

Aby wyraźniej podkreślić korelacje zachodzące między otwartością i przedsiębiorczością, przedstawiam własną propozycję reinterpretacji The Johari Window Model, która jeszcze wyraźniej akcentuje zachodzące między nimi korelacje. Nowa interpretacja wskazuje na wyraźne wychylenie poza granice komunikacji interpersonalnej i znacznie bardziej roz- 
szerza się w płaszczyźnie wertykalnej i horyzontalnej. Mamy tu do czynienia z uniwersalnym wymiarem komunikacji - w czasie i przestrzeni zarówno geograficznej, historycznej, jak i teoretycznej, gdzie komunikują się ludzie z różnych epok, kontynentów, mówiący różnymi językami, reprezentujący różne kultury. Dostrzegamy tu nie kończącą się rozmowę, wszechobecny dialog. Istotna staje się tu nie tylko samoświadomość podmiotu, ale także szeroko pojmowana świadomość - otaczającego świata, innych ludzi, dorobku kulturowego ludzkości. W takim zabiegu - The Johari Window Model staje się „dzietem otwartym”. Co w odniesieniu do Umberto Eco można rozumieć, że zostało odczytane od nowa, zostało,,rozszyfrowane”, „rozkodowane” na zupełnie nowy sposób. Jako „dzieło otwarte” zostaje przeze mnie odczytany jako model komunikacji międzyludzkiej - między światem subiektywnym $i$ intersubiektywnym, które pozostają ze sobą w dialektycznym związku, nie jest to jednakże dialektyka typu heglowskiego, domagająca się syntezy, konsensusu, ale ontologiczna - stająca się sposobem bycia, wyrażająca rozwój, ruch myśli, wewnętrzne sprzeczności, ilościowe i jakościowe zmiany.

Jednocześnie przyjmuję kantowski model epistemologiczny, w którym to podmiot kreuje przedmiot, albowiem odgrywa aktywną rolę poznawczą, nadając przedmiotowi atrybuty wynikające z kształtu aparatu poznawczego podmiotu.

Poniżej przedstawiam własną propozycję odczytywania The Johari Window Model oraz szczegółowy opis poszczególnych przestrzeni okna, ich reinterpretację.

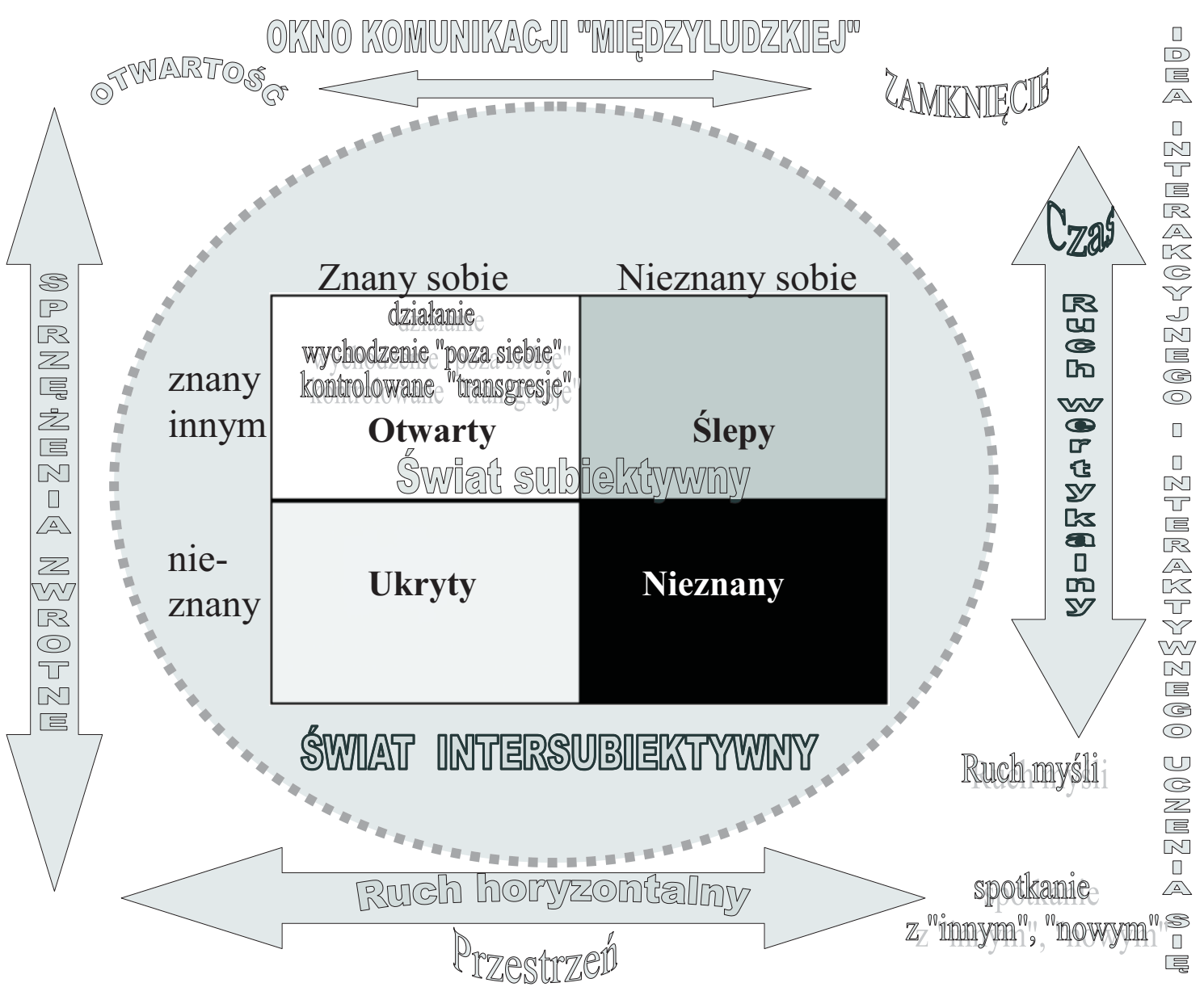

Źródło: opracowanie własne 
I - Okno eksponujące pierwsze górne od lewej pole (OTWARTY OBSZAR) - odczytuję jako obszar „swobodnej”, otwartej wymiany informacji, doświadczeń między Ja subiektywnym - moim subiektywnym światem - a światem intersubiektywnym. Niezwykle istotna jest tu jednak krytyczna refleksja nad przyjmowanymi i przekazywanymi wzajemnie treściami. Płaszczyzna tego okna będzie tym rozleglejsza, im swobodniejsza a zarazem racjonalniejsza będzie wzajemna transmisja wiedzy, doświadczeń, umiejętności - między światem subiektywnym i intersubiektywnym, im swobodniejszy (choć przefiltrowany przez naszą subiektywną racjonalność) będzie ich przepływ. Wielkość płaszczyzny tego okna zależna jest również od wzajemnego przyzwolenia obu światów na dokonywanie się nieustannych sprzężeń zwrotnych. Szerokie pole nr 1 informuje nas, że mamy do czynienia z ciągłym, „nieskrępowanym” dwustronnym ruchem.

W takiej wzajemnej interakcji (Ja - Świat) korzyść jest obopólna. Można tu dostrzec rodzaj dialektycznego związku między dwoma światami. Dzięki takiemu związkowi (Ja ) reprezentujące świat subiektywny czerpie doświadczenie, wiedzę, wsparcie od świata intersubiektywnego, zaś w miarę jego dorastania, rozwoju, emancypacji, nabywania różnorodnych umiejętności, doświadczeń, wzbogacania wiedzy przekazuje coraz więcej swoich „przetworzonych” i „przepracowanych” przez siebie ZASOBÓW (wiedza, umiejętności, doświadczenia, odkrycia etc.) światu intersubiektywnemu.

W przeciwieństwie do prezentowanego okna, w dwóch poniżej przedstawionych oknach obserwujemy jednostronny przepływ informacji, ruch jest zatem tylko $\mathrm{w}$ jednym kierunku. Nie ma tu swobodnych sprzężeń zwrotnych. Okna te mogą być zatem odczytywane jako metafora „lustra weneckiego".

TEN MODEL OKNA ILUSTRUJE DIALEKTYCZNY ZWIĄZEK ŚWIATA SUBIEKTYWNEGO I INTERSUBIEKTYWNEGO, MIĘDZY KTÓRYMI ZACHODZI SWOBODNA (CHOĆ BĘDĄCA POD KONTROLĄ) KOMUNIKACJA W CZASIE I PRZESTRZENI ORAZ WZAJEMNA TRANSMISJA I KONFRONTACJA PERSPEKTYW; WIELKOŚĆ TEGO POLA UZALEŻNIONA JEST W ZNACZNEJ MIERZE OD AKTYWNOŚCI PODMIOTU.

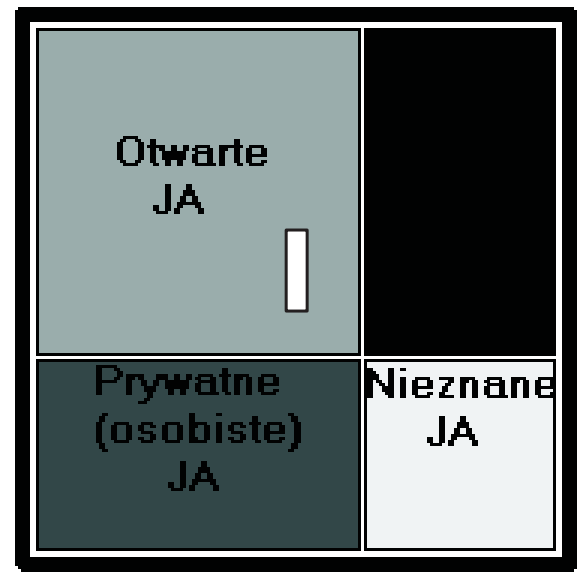

II - Okno eksponujące drugie dolne od lewej pole (UKRYTY OBSZAR) - odczytuję, jako stopień „ukrywania” naszego subiektywnego świata przed światem intersubiektywnym. Wskazana szeroka płaszczyzna oznacza, że świadomie decydujemy się na zamknięcie, w kręgu własnych doświadczeń, wiedzy. Pozbawiamy się tym samym możliwości spotkania z „,nowym”, „innym”, skonfrontowania subiektywnych doświadczeń z doświadczeniami intersubiektywnego świata, poruszamy się pośród znanych, wydeptanych ścieżek, zastygamy w (niejednokrotnie wygodnych) schematach. (Ja - Świat). Czasami pozostajemy w polu ukrytym ponieważ chcemy dać sobie czas na refleksję, przemyślenie, „uchwycenie perspektywy”, „złapanie” dystansu. Chodzi tu o to, aby owo „zatrzymanie” nie było „pustym, jałowym byciem". Nawet jeśli podejmiemy wysiłek poznawania, doświadczania świata na „własną rękę"- czytając wiele książek, studiując na uniwersytetach, poszukując samodzielnie odpo- 
wiedzi na pojawiające się coraz to nowe pytania., lecz nie podzielimy się nimi z innymi, nie damy przyzwolenia na wzajemną konfrontację owej wiedzy i doświadczeń, na zaistnienie dialogu ,polifonicznego" (za Henry A. Giroux i P. McLarenem). To i tak nie zapewnimy sobie ,pełnego" rozwoju, ponieważ nasze rozumienie siebie i świata okaże się jednowymiarowe, wyizolowane, mocno ograniczone osobistą perspektywą. Blokujemy tym samym szansę rozwoju naszej świadomości i samoświadomości. Okazuje się, że nie jesteśmy samowystarczalni i zdolni, by samookreślić się samodzielnie, potrzebujemy pomocy i porozumienia z innymi (Charles Taylor, 1995). Paul Ricoeur (2003) uważa, że bycie soba,(oznaka własnej „,sobości)”, wyraża się w zdolności człowieka do działania, zaś działać to być „poza sobq". Poznanie siebie dokonuje się przez interakcję społeczną (G. H. Mead, H. Blumer); przez Ja odzwierciedlone, przyjmowanie perspektyw innych, porównania społeczne (ja - inni) [M. Argyle 2001; Eliot Aronson, Timothy Wilson, Robin Akert 1997]. Jedynie podjęcie ryzyka wyjścia z „ukrycia” może wyzwolić nas z krępującego, „zamkniętego” schematu naszych doświadczeń, z „zasklepiającego” myślenia, pozwala na wzrost naszej świadomości i samoświadomości.

TEN MODEL WSKAZUJE NA STOPIEŃ ZAMKNIECIA NASZEGO SUBIEKTYWNEGO ŚWIATA (UKRYWANIA GO) PRZED ŚWIATEM INTERSUBIEKTYWNYM; BRAK KONFRONACJI, DIALOGU, RACJONALNEJ OTWARTOŚCI, KTÓRYM CZESTO TOWARZYSZĄ: BIERNOŚĆ, BRAK INICJATYWY, BRAK PRZEDSIĘBIORCOŚCI, BRAK KREATYWNOŚCI, NIECHĘĆ DO DZIAŁANIA.

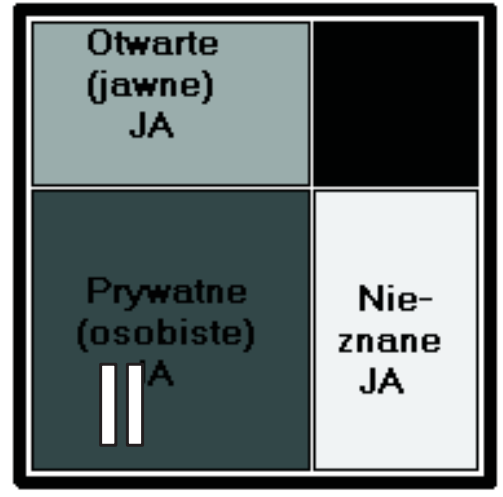

III - Model eksponujący trzecie górne od prawej pole (ŚLEPY OBSZAR) - odczytuję jako obszar naszej niewiedzy, nieświadomości zarówno dotyczącej nas samych, jak i otaczającego nas świata. Płaszczyzna ta obrazuje obszar wiedzy nieznanej nam, choć obiektywnie istniejącej. Obszar ślepy może być rezultatem różnorodnych „zamknięć”, „przymknięć”, „domknięć”, zarówno tych zależnych od nas, jak i niezależnych. Im bardziej zmniejszymy, obkurczymy ten obszar tym bardziej wzrośnie nasza świadomość i samoświadomość. Obserwacja tej płaszczyzny może okazać się niezwykle istotna z punktu widzenia rozwoju osobowego oraz edukacji, albowiem odzwierciedla stan naszej zgody (bądź niezgody), (możności bądź niemożności), (chęci - niechęci), (woli - braku woli), (gotowości - braku gotowości); (warunków sprzyjających - niesprzyjających) do rozwoju, działania, kreatywności, poszerzania wiedzy (otwartości). Płaszczyzna tego okna będzie tym mniejsza, i będzie się tym bardziej obkurczała, im więcej zdołamy wziąć „,zaczerpnąć od intersubiektywnego świata jego „mądrości”. Im więcej od niego przyswoimy, nauczymy się, i im lepiej to wykorzystamy w osobistej perspektywie. Płaszczyzna ta obkurczy się zatem wtedy, gdy poprzez naukę, wykształcenie, rozwój osobisty, konfrontację siebie z innymi, przez swoje racjonalne wybory i racjonalną otwartość, „poszukującą otwartość”) zechcemy „czerpać ze świata”, z jego ogromnych zasobów wiedzy i doświadczeń - to co najlepsze. Jak już wcześniej podkreślałam, świat subiektywny jest traktowany jako podmiot aktywny, który sam decyduje o tym kiedy i na co chce, a na co nie chce się otworzyć. Aby jednak rozróżniać „dobre” od „złego"” „najlepsze” od „najgorszego” musimy mieć pewną orientację (wiedzę, doświadczenia, „wie- 
dzę orientującą"). Tutaj upatruję dużej roli pedagogów, nauczycieli, którzy mogą pomóc człowiekowi w jego wychodzeniu z nieświadomości, niewiedzy poprzez doskonalenie jego orientacji w świecie, by mógł swobodniej się w nim poruszać. Płaszczyzna tego okna pobudza jednocześnie do refleksji pedagogicznej nad istotą i znaczeniem nauczyciela $\mathrm{w}$ procesie kształcenia, dokonujących się ,transgresji”.

TEN MODEL WSKAZUJE NA STOPIEŃ NASZEJ NIEŚWIADOMOŚCI INTERSUBIEKTYWNEGO ŚWIATA. JEST TO OBSZAR WIEDZY NIEZNANEJ NASZEMU SUBIEKTYWNEMU ŚWIATU. PŁASZCZYZNE TE MOŻEMY OBKURCZYĆ ZA SPRAWĄ WŁASNEJ AKTYWNOŚCI, INICJATYWY, KREATYWNOŚCI, PRZEDSIĘBIORCZOŚCI.

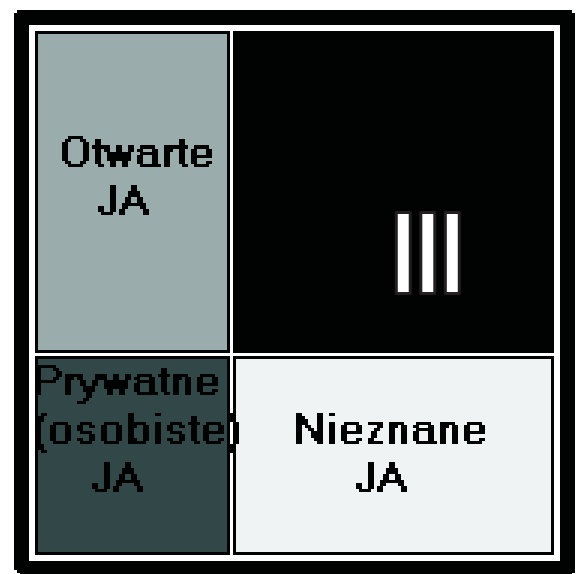

IV - Model eksponujący czwarte dolne od lewej pole (NIEZNANY OBSZAR) - odczytuję jako obszar wiedzy nieznany w ogóle nikomu. Odnosi się on zatem do tej wiedzy, której jeszcze nie odkryto, dotyczy wszystkiego, czego jeszcze nie poznano - zarówno w samym człowieku, jak i w otaczającym go świecie. Przekraczając samego siebie (,transgresje”), swoje własne granice, ograniczenia, bariery, lęki, kompleksy, rozwijając się i poszerzając swoją wiedzę, horyzonty myślowe i kreatywność - zwiększamy szanse na odkrywanie owych tajemnic zarówno w samych sobie, jak i w świecie.

Ta płaszczyzna okna wskazuje na tajemniczą i nieprzewidywalną naturę zarówno człowieka, jak i otaczającego go świata. Odnosi się również do wszelkich nierozpoznanych jeszcze zasobów, bogactw, cech, potencjałów, które mogą uwidocznić się (otworzyć) za sprawą naszej aktywności, przedsiębiorczości, chęci, nauki, rozwoju etc.

TEN MODEL OBRAZUJE OBSZAR WIEDZY NIEZNANY ANI ŚWIATU SUBIEKTYWNEMU, ANI INTERSUBIEKTYWNEMU; JEST TO OBSZAR NIEŚWIADOMOŚCI OBU ŚWIATÓW. PLASZCZYZNĘ IV MOŻNA ZMNIEJSZYĆ ZA SPRAWĄ AKTYWNOŚCI, PRZEDSIĘBIORCZOŚCI CZŁOWIEKA (POPRZEZ ODKRYWANIE NIEODKRYTEGO, POZNAWANIE NIEPOZNANEGO).

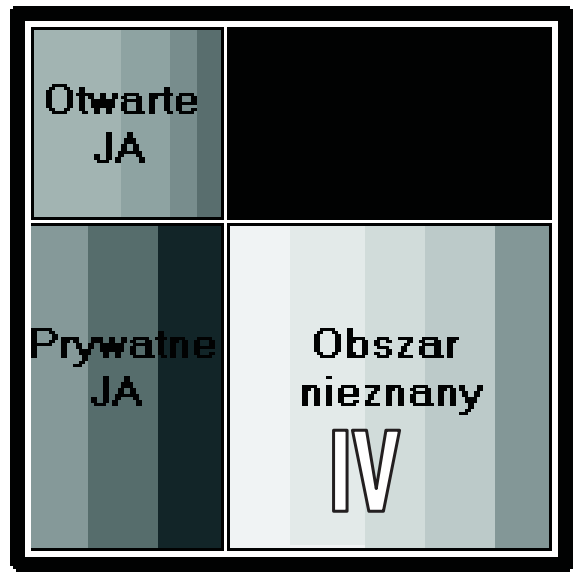


Model The Johari Window nie tylko opisuje i interpretuje jakość komunikacji międzyludzkiej. Ale przede wszystkim pozwala przewidywać różne jej aspekty, ponieważ umożliwia w nią pewien wgląd. Przez „szyby” okienne obserwujemy przepływające informacje, które opisują podmioty komunikujące się ze sobą. Przepływ danych jest dynamiczny. Widzimy, że sprzężenia zwrotne zachodzące między światem subiektywnym i intersubiektywnym są najbardziej efektywne i pożyteczne, gdy oba światy działają, komunikują się w relacji otwartej płaszczyzny (areny), gdy ich działania mają charakter synergiczny.

W nowej interpretacji Okna Johari znacznie wzrasta rola aktywności i inicjatywy obu światów. Im większa chęć i gotowość podmiotów do działania, im większą wykazują się przedsiębiorczością, kreatywnością, racjonalnością, tym obszar zielony staje się rozleglejszy. W kontekście powyższych rozważań zauważamy, że otwartość ma charakter dynamiczny. Jest procesem permanentnie dokonujących się zmian w obrębie naszej świadomości i samoświadomości. Oznacza rozwój, nieustanne stawanie się na nowo. Jej istotą jest refleksyjność, działanie, wychodzenie „poza siebie” (Paul Ricoeur, 2003) oraz kontrolowane „transgresje” (Józef Kozielecki, 1987). W tak pojmowaną otwartość wpisana zostaje ambiwalencja oraz „dezintegracja pozytywna” Kazimierz Dąbrowski (1979).

Otwartość manifestuje się w całej strukturze psychofizycznej człowieka, a nie w jakimś jej wybranym obszarze, fragmencie. Oznacza to, że otwartość znajduje swoje odzwierciedlenie w sposobie myślenia człowieka, w strategiach działania, przeżywanych i wyrażanych emocjach, komunikacji werbalnej i niewerbalnej.

Rozróżniłam trzy następujące płaszczyzny otwarcia - otwierania się:

- Do innych ludzi i świata - gdy bez obaw i lęku otwieramy się przed światem i innymi ludźmi. Jest to forma dzielenia się sobą z innymi (swoja wiedzą, doświadczeniami, informacjami o sobie.

- Na innych ludzi i na świat - gdy dajemy szanse „innym” oraz światu intersubiektywnemu (mam na myśli cały dorobek kulturowy ludzkości), aby otworzyli przed nami swój potencjał,(dajemy im dostęp do naszego świata subiektywnego), aby mogli dzielić się z nami swoją wiedzą, doświadczeniami, informacjami. Gdy stwarzamy właściwe warunki do poznawania polimorficznej natury świata i innych ludzi (np. za sprawą edukacji, dialogu „polifonicznego” oraz działania). Takie otwarcie siebie sprzyja rozwojowi naszej świadomości - co wydaje się istotne w kontekście rozwoju człowieka jego przedsiębiorczości.

- Otwieranie siebie przed sobą, pojmowane jako akt samoeksploracji. Gdy jesteśmy gotowi i dążymy do lepszego, „niepozorowanego” poznawania siebie.

Płaszczyzna pierwsza i druga wskazuje na gotowość do wzajemnej, „niepozorowanej” transmisji perspektyw, „dialogu międzyludzkiego” oraz poszukiwania sprzężeń zwrotnych (między światem subiektywnym i intersubiektywnym). Wyraża się w gotowości do nieustannego poszerzania i doskonalenia naszej wiedzy oraz orientacji w świecie, w inicjatywie i przedsiębiorczości podmiotu. Płaszczyzna trzecia dotyczy naszej samoświadomości i potrzeby jej nieustannego rozwoju.

Zauważamy, że istotą aktywności człowieka otwartego, przedsiębiorczego ma być ciągłe poznawanie wielowymiarowego, zmienialnego i nigdy nieprzewidywalnego do końca świata. Albowiem istotą otaczającego świata jest jego ciągle odkrywana zmienność, brak możliwości kategoryzacji. Oznacza to, że człowiek chcący w nim przetrwać, a tym bardziej odnieść w nim sukces, skazany zostaje na ciągłe eksperymentowanie, kwestionowanie obowiązujących norm (krytycyzm), nieustanne redefiniowanie otoczenia, ciągłe uczenie się nowego (w sytuacji ogromnej konkurencyjności), antycypowanie przyszłych stanów i sytuacji, musi wychodzić poza „podwójną pętlę”. Nie wystarczy bowiem dostosowywać się wyłącznie do oczekiwań innych, ani kwestionować tego, co pozornie oczywiste (zob. Stefan Kwiatkowski, 2000).

Należy podkreślić, że nowe odczytywanie „Okna” Johari - sytuuje człowieka w pozycji „ciągle poszukującego”, ciągle definiującego świat na nowo, narażając go tym samym 
na nieustające poczucie niepewności, dyskomfortu, ambiwalencji. Ale jedynie takie usytuowanie stanowi szansę na rzeczywisty rozwój i osiągnięcie „sukcesu” we współczesnym świecie.

\section{LITERATURA}

Kwiatkowski S., Przedsiębiorczość intelektualna, Wydawnictwo Naukowe PWN, Warszawa 2000.

Bauman Z., Ponowoczesność jako źródło cierpień, Wydawnictwo „Sic”, Warszawa 2000.

Delsol Ch., Przekraczanie, profanowanie, czyli granice jako problem ponowoczesności, [w:] Pytając o człowieka, myśl filozoficzna Józefa Tischnera, pod red. ks. W. Zuziaka, Wydawnictwo Znak, Kraków 2001.

Aronson E., Wilson T. D., Akert R. M., Psychologia społeczna, Wydawnictwo Zysk i S-ka, Poznań 1997.

Ricoeur P., O sobie samym jako innym, Wydawnictwo Naukowe PWN, Warszawa 2003.

Szkudlarek T., Edukacja w wieloznaczności: perspektywa postmodernistyczna , [w:] Odmiany myślenia o edukacji, red. J. Rutkowiak, Oficyna Wydawnicza IMPULS, Kraków 1995.

Zalewska E., Tożsamość zawodowa nauczyciela $w$ edukacji otwartej $i$ „edukacji zamkniętej”, [w:] Inspiracje otwarcia krytyki w edukacji, red. Rodziewicz E, Wydawnictwo Uniwersytetu Gdańskiego, Gdańsk 1995.

Rodziewicz E., Wiedza i edukacja (w): Inspiracje otwarcia, op. cit.

Kwieciński Z., Tropy - ślady - próby, Wydawnictwo EDYTOR, Poznań 2000.

Delors J., Edukacja. Jest w niej ukryty skarb, Raport dla UNESCO, Warszawa 1998.

Niebrzydowski L., Płaszczyński E., Przyjaźń i otwartość w stosunkach międzyludzkich, PWN Warszawa 1989.

Niebrzydowki L., Otwartość młodzieży w różnych stadiach rozwoju stosunków interpersonalnych, ,Ruch Pedagogiczny”, 1984, nr 4.

Kozielecki J., Koncepcje psychologiczne człowieka, Wydawnictwo Akademickie „Żak”, Warszawa 1998.

Kon I., Odkrycie ,ja”, Państwowy Instytut Wydawniczy, Warszawa 1987.

Fromm E., Ucieczka od wolności, Czytelnik, Warszawa 1993.

Bachtin M., Problemy literatury i estetyki, Czytelnik, Warszawa 1982.

Bauman T., Przełamywanie stereotypów w myśleniu o procesie kształcenia, [w:] Od pedagogiki ku pedagogii, red. E. Rodziewicz i M. Szczepska - Pustkowska, Wydawnictwo „EDYTOR”, Torun 1993.

Eco U., Czytanie świata, Wydawnictwo Znak, Kraków 1999.

Eco U., Trzecie zapiski na pudetku od zapałek, Wydawnictwo Historia i sztuka, Poznań 1997.

Buber M., Spojrzenie filozofa, [w:] Mosty zamiast murów, red. J. Stewarta, Wydawnictwo Naukowe PWN, Warszawa 2000.

Gadamer G. H., Rozum, słowo, dzieje, Państwowy Instytut Wydawniczy, Warszawa 2000.

Rorty R., Przygodność, ironia i solidarność, Wydawnictwo SPACJA, Warszawa 1996.

Bloom A., Umyst zamknięty, Wydawnictwo Zysk i S-ka, Poznań 1997.

Meighan R., Socjologia edukacji, Wydawnictwo Uniwersytetu Mikołaja Kopernika, Toruń 1993.

Toffler A., Trzecia fala, Państwowy Instytut Wydawniczy,, Warszawa 1997.

Miłosz Cz., Zniewolony umyst, Krajowa Agencja Wydawnicza, Kraków 1981.

Michalski C., Powrót człowieka bez właściwości, Wydawca - Casablanca studio, Warszawa 1997. 
Strumska-Cylwik L., Rozprawa doktorska napisana pod kierunkiem prof. dr hab. Jana Żebrowskiego, Gdańsk 2004.

Olejarczyk A., Otwartość jako kluczowa kategoria filozofii, [w:] Pisma filozoficzne - Tom LXV, O filozofii dzisiaj, red. R. Kozłowski, Wydawnictwo Naukowe Instytutu Filozofii UAM, Poznań 2000.

\section{STRONY INTERNETOWE I SŁOWNIKI:}

Mały słownik języka polskiego pod red. Stanisława Skorupki, Haliny Auderskiej, Zofii Łempickiej, Wiedza Powszechna, Warszawa 1974.

Słownik języka polskiego, pod red. Mieczysława Szymczaka, PWN, Warszawa 1979.

Strona Internetowa http://www.ipis.pl/artykul.php?dartykul+170\&poddział_Przedsiebiorca. (04.08.23).

Strona Internetowa: www.wsip.com.pl/Portal?secld_5H77ECO457MUY3A48M146K2, (04.08.22).

J. Luft, H. Ingham, „The Johari Window : a graphic model for interpersonal relations“, Univ. Calif. Western Training Lab. 1955, oraz Chris Javris, Five Leadership Practices, The Johari Window, A window onto interpersonal communication, Strona internetowa: http//courses. bus. ualberta. ca/oa-central/xarticles/Johari. htm; (02.04.02).

S. M. Jourard, Self disclosure, Communication, Strona internetowa: http//:physinto. ulb. ac. be/cit-courseware/research/theories. htm (02.04.02).

S. M. Jourard's Selected Writtings, Summary of Central Ideas 